\title{
Pengaruh Perubahan Nilai Tukar Rupiah Tengah US Dollar Terhadap Indeks Harga Saham Gabungan (IHSG) Di Bursa Efek Indonesia
}

\author{
SUDIRMAN \\ IAIN Sultan Amai Gorontalo \\ Email: yudih65@yahoo.co.id
}

\begin{abstract}
Abstrak
Penelitian ini bertujuan untuk mengkaji pengaruh perubahan nilai tukar rupiah tengah US dollar terhadap Indeks Harga Saham Gabungan di Bursa Efek Indonesia, tahun 2010 2015.Jenis penelitian adalah esploratif konfirmatif dengan alat analisis regresi sederhana pada data sekunder. Data yang digunakan adalah data time series periode bulan dari data perubahan nilai tukar rupiah tengah US Dollar dengan data perubahan Indeks Harga Saham Gabungan dari tahun 2010 - 2015. Pada penelitian ini ditemukan perubahan nilai tukar rupiah tengah US dollar berpengaruh positif terhadap Indeks Harga Saham Gabungan di Bursa Efek Indonesia selama periode yang diteliti.
\end{abstract}

\section{Kata kunci: nilai tukar, indeks harga saham gabungan}

\section{A. Pendahuluan}

Dalam upaya mendorong pertumbuhaan ekonomi nasional, pemerintah Indonesia senantiasa berupaya meningkatkan partisipasi masyarakat untuk memanfaatkan modalnya secara optimal melaui aktivitas investasi, baik oleh masyarakat dalam negeri maupun dengan menarik investor dari Negara lain untuk menanamkan modalnya di Indonesia secara intensif. Apabila partisipasi masayarakat untuk berinvestasi cendrung meningkat, maka pada saat yang sama akan mendorong pula menigkatnya aktivitas ekonomi nasional. Kondisi tersebut sangat dimungkinkan, karena didukung oleh ketersediaan modal kerja yang dapat dimanfaatkan oleh para perusahaan untuk mengembangkan aktivitas usahanya. Kemampuan oleh para perusahaan untuk mengoptimalkan pemanfaatan modal kerja yang mengalir ke pasar modal akan berimplikasi terhadap meningkatnya kebutuhan tenaga kerja. Dengan demikian, dapat mengurangi jumlah pengangguran dan kemiskinan serta mendorong meningkatnya kesejahteraan masyarakat yang pada akhirnya akan mendorong pula meningkatnya pertumbuhan ekonomi nasional.

Keputusan berinvestasi dapat dilakukan dengan dua cara, yaitu: pertama, mendirikan perusahaan (real investment) dan kedua, membeli aktiva finansial yang biasa disebut dengan sekuritas (financial investment), berupa saham dan obligasi di pasar modal. Pasar modal (capital market) merupakan salah satu sarana yang efektif dalam 
pembentukan modal dan alokasi dana yang diarahkan untuk meningkatkan partisipasi masyarakat guna menunjang pembiayaan pembangunan nasional. Keberadaan pasar modal bertujuan untuk menjembatani aliran dana dari pihak investor (pemilik dana) kepada pihak perusahaan yang membutuhkan dana, baik untuk keperluan ekspansi usaha ataupun untuk perbaikan struktur modal perusahaan.

Kebutuhan modal oleh perusahaan yang relatif besar serta tingginya minat masyarakat untuk berinvestasi mendorong pemerintah mendirikan Bursa Efek Indonesia. Bursa Efek didirikan untuk memudahkan masyarakat melakukan investasi dalam bentuk surat-surat berharga, dan juga untuk memudahkan perusahaan dalam memperoleh modal kerja. Tingginya minat masyarakat untuk berinvestasi akan meninkatkan pula minat perusahaan untuk go public. Dengan demikian, aktivitas di pasar modal akan meningkat, karena sebagai akibat dari meningkatnya jumlah emiten, jumlah surat-surat berharga yang diperdagangkan, dan peningkatan volume transaksi yang terjadi pada setiap saat. ${ }^{1}$

Peningkatan nilai transaksi dan volume transaksi saham, akan mendorong pula meningkatnya kinerja pasar modal yang tercermin dari meningkatnya nilai indeks harga saham gabungan (IHSG). Indeks dibuat dan dijadikan sebagai tolak ukur (lead indicator) dan sekaligus sebagai alat untuk memantau kecenderungan perkembangan bisnis dan perkembangan tingkat harga saham yang diperdagangkan di pasar modal.

Perkembangan pasar modal pada suatu negara, dapat dilihat dari tingginya jumlah saham yang diperdagangkan, jumlah perusahaan (emiten) yang terdaftar (listed), volume transaksi, nilai transaksi, dan Indeks Harga Saham Gabungan (IHSG), serta nilai kapitalisasi pasar yang kesemua itu telah membawa konsekuensi tertentu bagi investor, emiten, dan pelaku pasar modal lainnya. Berikut data perkembangan Pasar Modal Indonesia ditunjukkan pada Tabel 1.1, yakni, meliputi: perkembangan jumlah perusahaan yang go public, total perdagangan, indeks harga saham gabungan (IHSG), dan jumlah saham beredar. ${ }^{2}$

\footnotetext{
${ }^{1}$ Husnan S., Dasar-Dasar Teori Portofolio dan Analisis Sekuritas (UPP-AMP, 1989), h. 13.

${ }^{2}$ Bursa Efek Indonesia, JSX Monthly Statistik, Vol. 20 No. 1-12, 2016
} 
Tabel 1.1

PERKEMBANGAN KINERJA PASAR MODAL INDONESIA

(BURSA EFEK INDONESIA)

TAHUN 2009 SAMPAI DENGAN 2015

\begin{tabular}{|c|c|c|c|c|c|}
\hline Tahun & $\begin{array}{c}\text { Jumlah } \\
\text { Emiten }\end{array}$ & $\begin{array}{c}\text { Volume Transaksi } \\
\text { (lembar saham) }\end{array}$ & Nilai Transaksi (Rp) & IHSG & $\begin{array}{c}\text { Jumlah Saham yang } \\
\text { Tedaftar }\end{array}$ \\
\hline 2009 & 398 & 289.813 .126 .019 & 241.810 .306 .117 & 2.534 .35 & 1.465 .655 .107 .119 \\
\hline 2010 & 420 & 1.330 .865 .192 .681 & 1.176 .237 .419 .584 .780 & 3.703 .512 & 1.894 .828 .442 .341 \\
\hline 2011 & 440 & 1.203 .549 .994 .411 & 1.223 .440 .506 .946 .820 & 3.821 .992 & 2.198 .133 .269 .765 \\
\hline 2012 & 459 & 1.053 .762 .087 .909 & 1.116 .113 .252 .327 .560 & 4.316 .687 & 2.438 .408 .332 .470 \\
\hline 2013 & 483 & 1.342 .657 .273 .695 & 1.522 .112 .357 .663 .490 & 4.274 .177 & 2.827 .794 .866 .851 \\
\hline 2014 & 506 & 1.327 .015 .645 .906 & 1.453 .392 .360 .918 .190 & 5.226 .947 & 3.084 .060 .283 .305 \\
\hline 2015 & 521 & 1.446 .314 .004 .109 & 1.406 .360 .182 .311 .801 & 4.593 .008 & 3.342 .583 .729 .127 \\
\hline
\end{tabular}

Sumber: Bursa Efek Indonesia, JSX Monthly statistik, 2009- 2016.

Pada tabel 1.1 di atas mengambarkan pertumbuhan Pasar Modal Indonesia dalam kurun waktu tujuh tahun terakhir, meliputi pertumbuhan nilai transaksi,dan pergerakan IHSG,volume transaksi, serta pertumbuhan jumlah emiten yang terus meningkat, dari tahun 2009 hingga tahun 2015. Perkembangan pasar modal Indonesia dalam kurung waktu tujuh tahun terakhir cenderung mengalami peningkatan, dan bahkan pada tahun 2014 menunjukan pencapaian yang cukup tinggi, yaitu sebesar 5.226.947. Pencapaian tersebut, merupakan rekor baru. Sementara pada tahun 2015 IHSG kembali mengalami penurunan, yaitu pada akhir tahun nilai IHSG ditutup pada posisi 4.593.008 lebih rendah dari tahun sebelumnya.

Pergerakan IHSG yang cenderung berfluktuasi dapat dijadikan sebagai indikator penentu (lead indicator) ekonomi untuk melihat kearah mana bisnis berkembang dimasa akan datang. Indeks harga saham gabungan pada dasarnya mencerminkan harga-harga seluruh saham yang diperdagangkan dalam waktu tertentu yang membentuk nilai indeks saham gabungan. Data tersebut, disajikan pada tabel 1.2 berikut ini: 
Tabel 1.2

PERKEMBANGAN INDEKS RATA-RATA SAHAM

DIBURSA EFEK INDONESIA

DESEMBER 2009-2015

\begin{tabular}{|c|c|c|c|c|c|c|c|}
\hline Indeks & 2009 & 2010 & 2011 & 2012 & 2013 & 2014 & 2015 \\
\hline Kurs & 9.065 & 8.991 & 9.068 & 9.690 & 12.189 & 12.440 & 13.795 \\
Change & $381 \boldsymbol{\nabla}$ & $74 \boldsymbol{\nabla}$ & $77 \boldsymbol{\Delta}$ & $622 \boldsymbol{\Delta}$ & $2.499 \boldsymbol{\Delta}$ & $251 \boldsymbol{\Delta}$ & $1.355 \boldsymbol{\Delta}$ \\
\hline IHSG & 2.534 .356 & 3.703 .512 & 3.816 .687 & 4.316 .687 & 4.274 .177 & 5.226 .947 & 4.598 .008 \\
Change & $86.98 \boldsymbol{\Delta}$ & $46.13 \boldsymbol{\Delta}$ & $3.20 \boldsymbol{\Delta}$ & $12.94 \boldsymbol{\nabla}$ & $-0.98 \boldsymbol{\nabla}$ & $22.29 \boldsymbol{\Delta}$ & $12.13 \boldsymbol{\nabla}$ \\
\hline
\end{tabular}

Sumber: Bursa Efek Indonesia, JSX Monthly statistik, 2009-2016 (data diolah)

Pada tabel 1.2 tersebut di atas, terlihat bahwa perkembangan IHSG dari tahun 2009 sampai dengan tahun 2015 menunjukan pergerakan yang cukup fluktuatif dari tahun ke tahun. Kondisi tersebut, dipicu oleh masih melemahnya pertumbuhan ekonomi nasional, sehingga kondisi tersebut ikut mempengaruhi minat para investor untuk melakukan transaksi portofolio di Pasar Modal Indonesia yang juga cenderung menurun, sehingga kinerja pasar pasar modal Indonesia juga mengalami penurunan pada periode yanga sama. kemudian, pada tahun 2014 kondisi perekonomian nasional mulai membaik, maka pada saat yang sama IHSG juga kembali mengalami kenaikan hingga mencapai level tertinggi, yaitu sebesar 5.226.947, akan tetapi pada tahun 2015 IHSG kembali mengalami penurunan sebesar 12.13 persen. Penurunan IHSG sebagai akibat dari melemahnya nilai tukar rupiah terhadap US dollar, yang berdampak buruk terhadap perekonomian nasional, karena kondisi tersebut memicu meningkatnya laju inflasi sebagai akibat dari meningkatnya harga barang-barang impor yang juga cenderung diikuti oleh peningkatan harga barang-barang domestik.. kondisi tersebut, membuat para investor menjadi semakin berhati-hati untuk melakukan transaksi portofolio, dan bahkam mereka cenderung menjual portofolionya, akibatnya pergerakan IHSG cenderung menurun. Kondisi tersebut, terus berlangsung pada tahun $2015 .^{3}$

Perubahan nilai kurs sering kali mengkibatkan terjadinya pergerakan pada IHSG di Bursa Efek Indonesia. Mengingat Indonesia sebagai negara berkembang (emergen market), mengakibatkan kinerja pasar modal Indonesia sering kali mengalami fluktuasi akibat isu perekonomian global, seperti perubahan nilai kurs. Kondisi tersebut, dapat terjadi karena

${ }^{3}$ Bursa Efek Indonesia, JXS Monthly Statistic, Desember 2009-2015 
tingginya kebutuhan terhadap barang-barang impor, sehingga pergerakan nilai kurs sangat rentang terhadap perekonomian nasional. Disamping itu, pemerintah Indonesia juga banyak mempergunakan utang luar negeri dalam menutupi kekurangan anggaran pendapatan dan belanja Negara, sehingga kebutuhan terhadap mata uang US dollar cenderung meningkat. Tingginya kebutuhan terhadap mata uang US dollar mengakibatkan perekonomian Indonesia sangat rentang terhadap pergerakan nilai kurs. Apabila nilai US dollar cenderung menguat, maka pada saat yang sama perekonomian nasional juga ikut tertekan dan akan berdampak pula terhadap pergerakan IHSG yang juga cenderung menurun, demikian pula sebaliknya.

\section{B. Tinjauan Teori dan Konsep}

\section{Saham}

Saham menurut Buku Panduan Investasi di Pasar Modal Indonesia saham adalah sertifikat yang menunjukan bukti kepemilikan suatu perusahaan dan pemegang saham memiliki hak klaim atas penghasilan dan aktivitas perusahaan. Harga sebuah saham sangat dipengaruhi oleh hukum permintaan dan penawaran, harga suatu saham akan cenderung naik bila suatu saham mengalami kelebihan permintaan dan cenderung turun jika terjadi kelebihan penwaran. Saham adalah salah satu Efek pasar umumnya dijual di pasar modal (Bursa Efek) adalah saham. Saham adalah bukti penyertaan modal pada suatu perseroan terbatas. ${ }^{4}$

Saham yang di terbitkan emiten ada dua macam yaitu saham biasa (common stok) dan saham istimewa (preffed stok). Perbedaan saham ini berdasarkan pada hak yang melekat pada saham tersebut. Hak tersebut meliputi hak atas penerimaan deviden, memperoleh bagian kekayaan jika perusahaan dilikuditas setelah dikurangi semua kewajiban. Saham istimewa didahulukan dalam pembagian deviden dan juga apabila perusahaan dilikuidasi, maka pemilik saham istimewa didahulukan pula mendapatkan harta kekayaan perusahaan setelah semua kewajiban telah diluasi. Sementara, saham biasa akan mendapatkan deviden setelah dlakukan pembagian kepada saham istimewa, begutpula dalam pembagian dari bagian harta kekayaan perusahaan jika mengalami likuidasi. ${ }^{5}$

\footnotetext{
${ }^{4}$ Swasta Basu, "Investment Performance of Common Stock in Relation to Their Price Rations: A Test of the Market Efficiency Hypotesis," Journal of Finance, Vol. 23, 1997.

${ }^{5}$ http://id.wikipedia.org/wiki/ saham \# riwayat-saham (diakses tgl 13 november 2015)
} 


\section{Indeks Harga Saham}

Indeks harga saham adalah suatu indikator yang menunjukan pergerakan harga saham dalam suatu periode. Indeks ini berfugsi sebagai indikator trand pasar, artinya pergerakan indeks mengambarkan kondisi pasar pada suatu saat, apakah keadaan pasar sedang aktif atau sedang lesu.

Setiap bursa efek akan menetapkan angka basis indeks yang berbeda, yaitu ada yang dimulai dengan basis 100, 500 atau 1.000 jenis indeks dapat dikelompokkan menjadi tiga, yaitu: ${ }^{6}$

a. Indeks harga saham individual.

b. Indeks saham parsial.

c. Indeks harga saham gabungan.

Pergerakan indeks menjadi indikator penting bagi para investor untuk menentukan apakah mereka akan menjual, menahan atau membeli satu atau beberapa saham. Karena harga-harga saham bergerak dalam hitungan detik dan menit, maka nilai indeks pun bergerak turun naik dalam hitungan waktu yang cepat pula. Indeks harga saham terbagi menjadi tiga yaitu: ${ }^{7}$

1) Indeks Harga Saham Individual

Mengunakan indeks harga masing-masing saham terhadap harga dasarnya, atau indeks masing-masing saham yang tercatat di BEI. Indeks harga saham individu hanya menunjukan perubahan dari suatu harga saham suatu perusahaan. Indeks ini tidak bisa untuk mengukur harga dari suatu perusahaan tertentu. Atau dapat dikatakan bahwa indeks individual saham merupakan suatu nilai yang mempunyai fungsi untuk mengukur kinerja kerja suatu saham tertentu terhadap harga dasarnya. Perhitungan indeks harga saham individu dilakukan dengan rumus berikut:

$$
|H S|=\frac{\text { jumlah saham beredar } x \text { harga pasar }}{\text { jumlah saham beredar } x \text { nilai dasar }} \times 100
$$

2) Indeks Harga Saham Parsial

Setiap pihak dapat menciptakan indeks harga yang terdiri dari beberapa jenis saham untuk kepentingan sendiri. Setiap pihak dapat menciptakan indeks harga saham yang 180.

${ }^{6}$ Muhammad Syamsul. Pasar Modal dan Manajemen Portofolio. Surabaya: Airlangga 2006), h. 179-

${ }^{7}$ Muhammad Syamsul, Pasar Modal, h.183-184. 
terdiri dari beberapa jenis saham untuk kepentingan sendiri. Apabila indeks harga saham parsial tersebut ternyata baik digunakan sebagai pedoman oleh investor, maka indeks tersebut akan laris diperdagangkan. Misalnya indeks nikkei S\&P 100 adalah indeks gabungan dari 100 jenis saham di Amerika Serikat. Indeks harga saham parsial tersebut lebih laku diperdagangkan daripada indeks harga saham gabungan (composite index). Rumus yang digunakan untuk menghitung indeks harga saham parsial adalah:

$$
\text { Indeks saham } 100=\frac{\sum^{100} \text { kapitalisasi pasar) }}{\sum_{\Sigma} \text { (nilai dasar) }} \times 100
$$

Di mana:

Indeks $100=$ jumlah kapitalisasi pasar 100 emiten dibagi dengan jumlah nilai dasar dari 100 emiten kemudian dikalikan dengan 100 sebagai angka dasar

Kapitalisasi pasar $=$ saham beredar $\mathrm{x}$ harga pasar per unit saham

Total nilai dasar $=$ jumlah saham beredar $\mathrm{x}$ nilai dasar per unit saham

Indeks 100 berarti indeks dari 100 jenis saham.

\section{3) Indeks Harga Saham Gabungan ( IHSG)}

Indeks harga saham gabungan (IHSG) akan menunjukan pergerakan harga saham secara umum yang tercatat di bursa efek. Indeks inilah yang paling banyak dugunakan dan dipakai sebagai acuan tentang perkembangan kegiatan di pasar modal. IHSG ini bisa untuk menilai situasi pasar secara umum atau mengukur apakah harga saham mengalami kenaikan atau penurunan. Indeks harga ini melibatkan seluruh harga saham yang tercatat di bursa.

Indeks harga saham gabungan (Composite Stock Price Indeks $=$ CSPI) merupakan indeks gabungan dari seluruh jenis saham yang tercatat di bursa efek. Cara perhitungan IHSG sama dengan indeks harga saham parsial, yang berbeda hanya jumlah emiten. Indeks Harga Saham Gabungan (IHSG) pada dasarnya mencerminkan harga-harga seluruh saham yang diperdagangkan dalam waktu tertentu dibagi dengan nilai pasarnya dikalikan 100 persen di Bursa Efek Indonesia (BEI). IHSG dihitung setiap hari atau setiap detik selama jam perdagangan. IHSG berubah setiap hari karena (1) perubahan harga pasar yang terjadi setiap hari dan (2) adanya saham tambahan. Penambahan jumlah saham beredar berasal dari emisi baru, yaitu masuknya emiten baru yang tercatat di bursa efek, atau terjadi tindakan 
corporate action berupa split, rifh, waran, deviden saham, saham bonus, dan saham konversi. ${ }^{8}$

Adapun perhitungan indeks harga saham gabunagn dilakukan dengan rumus berikut:

\section{IHSG Nilai Pasar=jumlah saham tercatat x Harga Terakhir $\times 100$ \\ Nilai Dasar=jumlah saham tercatat $x$ Harga Perdana}

Keterangan:

IHSG = Indeks Harga Saham Gabunagn hari ke-1

Nilai Pasar = Rata-rata tertimbang nilai pasar (jumlah lembar saham tercatat di bursa dikali dengan harga pasar per lembarnya) dari saham umum dan saham preferen pada hari ke-t

Nilai Dasar = sama dengan nilai pasar tetapi dimulai dari tanggal 10 agustus 1982.

\section{Manfaat Indeks Harga Saham Gabungan}

Indeks harga saham gabungan ( IHSG) berguna untuk melihat perubahan harga saham secara keseluruhan di pasar. Baik kenaikan maupun penurunan harga saham bisa di lihat dari kenaikan dan penurunan IHSG ini. Diamping itu, manfaat lain dari Indek harga saham, yaitu sebagai berikugt: ${ }^{9}$

a. Indeks dapat digunakan untuk menghitung total imbal hasil dari pasar secara agregat atau beberapa komponen pasar pada priode waktu tertentu dan menggunakan tingkat pengembalian tersebut sebagai tolak ukur untuk menilai kinerja dari portofolio individu.

b. Untuk mengembangkan portofolio indeks

c. Indeks dapat pula digunakan untuk menguji faktor-faktor yang mempengaruhi pergerakan harga saham secara agregat.

d. Perubahan harga historis dapat digunakan untuk memprediksi pergerakan harga di masa depan.

e. Resiko yang relevan dengan resiko aset individual (saham) adalah resiko sistematik, yang merupakan hubungan antara tingkat imbal hasil resiko aset dan tingkat imbal hasil untuk portofolio pasar resiko aset. Dengan demikian, pada saat menghitung resiko

\footnotetext{
${ }^{8}$ Samsul Muhammad. Manajemen portofolio dan pasar modal. Airlangga, 2006: 179).

${ }^{9}$ http://id.wikipedia.org (diakses tgl 20 november 2015)
} 
aset individual perlu untuk mengkaitkan tingkat pengembaliannya dengan imbalan hasil dari indeks pasar agregat yang dapat digunakan sebagai proxy dari portofolio pasar resiko.

\section{Pasar Modal dan Ideks Harga Saham Gabungan (IHSG)}

Pada dasarnya kinerja pasar modal dapat dievaluasi dengan indikator indeks, indeks dibuat dan dijadikan sebagai tolok ukur (lead indicator) dalam mengevaluasi kinerja pasar modal, dan bahkan indeks juga dijadikan sebagai indikator ekonomi untuk mencermati kondisi perekonomian secara makro. Dari berbagai penelitian menunjukkan bahwa pasar saham dan aktivitas ekonomi bergerak dengan siklus pola yang serupa. Perubahan pada pasar saham cenderung akan diikuti pula oleh perubahan pada kondisi bisnis. Karena itu, indeks harga saham kemudian menjadi salah satu komponen utama indikator ekonomi (leading indicator economic) yang secara konsisten memberikan indikasi tentang adanya perubahan aktivitas bisnis, dan juga sebagai landasan analisis statistik atas pasar terakhir. Manfaatnya menjadi lebih karena dibandingkan dengan indikator-indikator lain yang memiliki rentang waktu yang cukup panjang, indeks harga saham tersedia setiap waktu dan selalu dapat dimonitor. ${ }^{10}$

\section{Hubungan Nilai Tukar Rupiah/US Dollar Terhadap Indek Harga Saham Gabungan (IHSG)}

Terdapat dua pendekatan teori yang dikembangkan dalam literatur untuk menentukan hubungan antara kurs mata uang dengan harga saham, yaitu: pertama, good market approach (Dornbusch \& Fischer, 1980) menyatakan perubahan mata uang atau kurs mempengaruhi competitiveness suatu perusahaan, yang selanjutnya mempengaruhi pendapatan perusahaan atau cost of fund dan selanjutnya harga sahamnya. Berdasarkan macro basis dampak fluktuasi kurs mata uang terhadap pasar modal sangat tergantung pada tingkat keterbukaan ekonomi domestik dan kesinambungan neraca perdagangan. Kedua, portfolio balance approach (Franke 1993) dimana menekankan peranan capital account transactions. Kenaikan return saham (rising stock market) akan menarik capital flow yang selanjutnya akan meningkatkan demand mata uang domestik dan menyebabkan kurs mata uang terapresiasi. Sekalipun menurut teori terdapat causal relationship antara kurs mata

\footnotetext{
${ }^{10}$ A. Michael Berry, Edwin Burmeister, and Majorie B. Mc Elroy. "Risks Using Known APT Factors." Financial Analysis Journal, Vol 44, 1988.
} 
uang dengan harga saham, bukti yang ada menunjukkan hubungan yang lemah diantara keduanya pada tataran mikro. ${ }^{11}$

Secara teori, hubungan nilai tukar rupiah/US dollar dengan saham dapat dijelaskan melalui teori penentuan kurs kurva asing. Menurut Bailie and McMahon (1990), salah satu pendekatan yang digunakan dalam penentuan kurs valuta asing adalah pendekatan keseimbangan portofolio. Dalam analisa keseimbangan portfolio, nilai tukar rupiah/ US dollar dapat digabungkan dengan aset financial lain seperti saham. Saham dan obligasi merupakan dua aset financial yang saling menggantikan. Demikian pula antara mata uang rupiah dengan mata uang dollar memiliki. posisi yang bisa saling menggantikan, tergantung dari nilai tukar masing-masing mata uang. Investor akan memilih memgang dari salah satu mata uang yang meiliki nilai tukar yang kuat. Apabila nilai tukar mata uang domestik terdepresiasi, maka nilai impor akan cenderung meningkat, karena meningkatnya harga barang-barang impor, dan sebaliknya volume ekspor akan meningkat karena harga barangbarang domestic menurun. ${ }^{12}$

Sejalan dengan itu, maka diperlukan demand ekspor barang yang elastis guna meningkatkan aliran uang yang tinggi bagi perusahaan domestik. Meningkatnya arus modal akan dapat mendorong perusahaan untuk meningkatkan kinerjanya karena didukung oleh ketersediaan dana yang cukup. Meningkatnya aliran dana terhadap perusahaan domestik memungkinkan untuk melakukan ekspansi usaha maupun melakukan perbaikan secara menyeluruh, sehingga dapat meningkatnya kinerja oleh setiap perusahaan. Informasi tersebut adalah merupakan informasi positif oleh para investor karena meningkatnya knerja emiten akan meningkatkan pula expectasi return dalam bisnis saham, sehingga akan memicu meningkatnya permintaan terhadap berbagai jenis saham. Apabila jumlah permintaan terhadap berbagai jenis saham meningkat, maka akan mendorong nilai indeks harga saham gabungan (IHSG) bergerak naik. ${ }^{13}$

\footnotetext{
${ }^{11}$ Louis K.C. Chan, Yasushi Harmao, and Josef Lakonishok, "Can Fundamentals Predict Japanase Stock Returns,” Financial Analysist Journal, No. 4, Vol 49 Juli/Agustus, 1993. Stock Returns"

${ }^{12}$ Louis K.C. Chan, Yasushi Harmao, and Josef Lakonishok, "Can Fundamentals Predict Japanase

${ }^{13}$ Prasanna Chandra. Investment Analysis and Portfolio Management. Second Edition, CFM-THM Professional Series in Finance, (New Delhi, Tata McGraw-Hill Publishing Company Limited, 2005), h. 23.
} 
Persamaan nilai kurs valas menurut model keseimbangan portofolio di tunjukkan oleh persamaan berikut: ${ }^{14}$

$$
S_{t}=S\left(M_{t} \cdot B_{t} \cdot F_{t} \cdot{ }^{*}{ }_{t}\right)
$$

\section{Keterangan:}

$\mathrm{S}_{\mathrm{t}}$ adalah nilai periode $\mathrm{t}$,

$\mathrm{M}_{\mathrm{t}}$ adalah suplai uang domestik,

$\mathrm{B}_{\mathrm{t}}$ adalah obligasi domestic,

$F_{t}$ adalah obligasi luar negeri, dan

$\mathrm{r}_{\mathrm{t}}$ adalah suku bunga internasional.

Selanjutnya, aset mempunyai sifat saling mengaitkan secara tidak sempurna. Berdasarkan konsep ini, setiap perubahan kekeyaan akan berdampak pada meningkatnya permintaan aset finansial lain dan adanya subtitusi suatu aset finansial dengan aset finansial lain yang lebih menguntungkan. Dalam analisis keseimbangan portofolio, nilai tukar rupaiah/US dollar dapat digabungkan dengan aset finansial lain seprti saham, karena saham dan obligasi merupakan dua aset finansial yang saling menggantikan.

Teori paritas daya beli adalah sebuah cara meramalkan kurs keseimbangan neraca pembayaran. Kurs keseimbangan adalah kurs yang akan menyeimbangkan nilai impor suatu negara. Jika nilai impor lebih besar dari pada nilai ekspornya, maka uang negera tersebut akan mengalami depresiasi (melemah). Penurunan nilai mata uang domestik terhadap nilai mata uang asing akan membuat harga dari berbagai komoditi ekspor menjadi murah dan sebaliknya harga barang impor mebnjadi mahal. Rendahnya harga produk dalam negeri akan mempengaruhi perolehan laba perusahaan domestik, sehingga akan berdampak terhadap penurunan harga saham dan permintaan terhadap berbagai jenis saham di pasar modal. Apabila harga saham serta permintaan terhadap berbagai jenis saham menurun, maka akan menyebabkan pula nilai indeks harga saham gabungan (IHSG) menurun, sebagai refrentasi dari menurunnya harga rata-rata saham yang diperdagangkan di pasar modal. $^{15}$

\footnotetext{
${ }^{14}$ Louis K.C. Chan, Yasushi Harmao, and Josef Lakonishok, "Can Fundamentals Predict Japanase Stock Returns"

${ }^{15}$ Damodaran, Aswath. Investment Valuation: Tools and Techniques for Determine the Value of Any Asset (New York. John Wiley \& Sons, Inc, 1996)
} 


\section{B. Kerangka Konseptual}

Di dalam penelitian ini mengunakan variabel nilai tukar sebagai variabel makro ekonomi yang berpengaruh terhadap indeks harga saham gabungan (IHSG) di bursa efek.

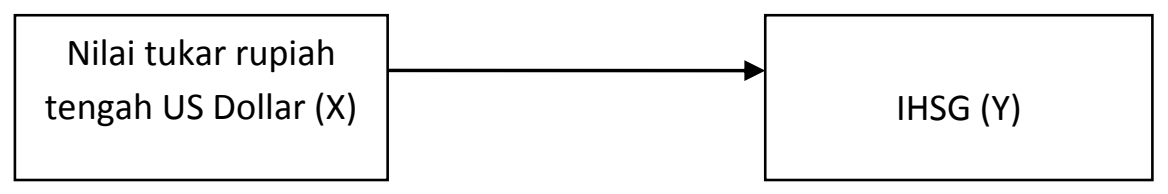

\section{Analisis Hasil penelitian}

Untuk mengetahui dan menganalisis pengaruh perubahan variabel makro ekonomi terhadap Indeks Harga Saham Gabungan. Dalam hal ini, variabel yang digunakan pada penelitian ini, yaitu: perubahan nilai tukar rupiah tengah kurs (X), terhadap indeks harga saham gabungan (Y), maka dilakukan analisis statistik yaitu analisis regresi sederhana dengan menggunakan data time series selama enam tahun pada data periode bulanan. Hasil estimasi dapat dilihat pada formulasi berikut ini:

$$
\mathrm{Y}=132484.504+276.146
$$

Nilai koefisien regresi pada variable independen, nilai $R$, nilai $\mathrm{R}^{2}$, nilai adjust dan $\mathrm{t}$ hitung dapat dilihat pada tabel 4.1 .3 berikut:

Tabel 1.5

Hasil Estimasi Analisis Regresi Pada Variabel Independen Terhadap Variabel Dependen

\begin{tabular}{|c|c|c|c|c|}
\hline Variabel & Koefisien $\beta$ & $\begin{array}{c}\text { Standar } \\
\text { Error }\end{array}$ & $\begin{array}{c}\text { Nilai t } \\
\text { hitung }\end{array}$ & Sig \\
\hline Constan & 132484.504 & 39446.869 & 3.352 & $\left.0,001^{* *}\right)$ \\
\hline $\mathrm{X}$ & 276.146 & 36.964 & 7.417 & $\left.0,000^{*}\right)$ \\
\hline $\mathrm{R}=0.666$ & $\mathrm{R}^{2}=0,444 \quad \mathrm{R}$ adjust $=0,436 \quad \mathrm{~N}=72 \mathrm{~K}=2$ \\
$\mathrm{Sig}=0,05$ &
\end{tabular}

Beberapa keputusan yang dapat diambil dari Tabel 1.5 adalah pertama, nilai $\mathrm{R}=0.666$ adalah nilai koefisien korelasi, nilai ini berarti hubungan antara variabel independen, yaitu: perubahan nilai tukar rupiah terhadap dollar $(\mathrm{X})$, terhadap variabel 
dependen yaitu indeks harga saham gabungan (Y) adalah cukup kuat. Nilai $\mathrm{R}^{2}=0,444$ adalah koefisien determinasi. Nilai ini berarti variasi variabel independen yang dapat menjelaskan variabel dependen sebesar $44,4 \%$ persen dan sisanya 55,6 persen variasi variabel lain yang tidak dijelaskan dalam model. Dengan demikian model ini sangat layak.

Kedua, Uji t digunakan untuk menguji secara parsial pengaruh variabel independen terhadap variabel dependen. Dari hasil estimasi diperoleh nilai konstanta sebesar 1322484,504. Nilai ini berarti, jika nilai tukar rupiah terhadap dollar (X) konstan, maka nilai indeks harga saham (Y) sebesar 1322484,504 poin.

Pengaruh perubahan nilai tukar rupiah terhadap US Dollar (X) terhadap indeks harga saham gabungan (Y). Dari hasil estimasi diperoleh nilai koefisien regresi perubahan nilai tukar rupiah terhadap US dollar (X) sebesar 276.145. Nilai ini berarti, jika nilai tukar rupiah tengah US dollar (X) ditingkatkan/diturunkan sebesar 1 satuan, maka nilai indeks harga saham (Y) akan meningkat /menurun pula sebesar 276.145 poin. Dan nilai t hitung = 7.471 signifikan $=0,000$, maka ini berarti t hitung lebih Besar dari t tabel 2.000, dengan tingkat signifikan 5\%. Maka Ho ditolak dan $\mathrm{H}_{1}$ diterima. Dengan demikian terdapat pengaruh yang signifikan antara variabel $(\mathrm{X})$ terhadap $(\mathrm{Y})$.

\section{E. Pembahasan Hasil Penelitian}

Pada penelitian ini akan membahasa mengenai pengaruh nilai tukar rupiah tengah US Dollar terhadap IHSG di Bursa Efek Indonesia Priode Tahun 2010 sampai tahun 2016. Pada penelitian ini lebih ditekankan pada aspek (why) suatu hubungan atau pengaruh secara signifikan maupun tidak signifikan. Untuk menjelaskan hal tersebut, maka akan dibangun sebuah argumen-argumen yang berbasis teori, empiris dan praktis.

Hasil penelitian membuktikan bahwa nilai tukar rupiah terhadap/ US dollar berpengaruh positif dan signifikan terhadap Indeks Harga Saham Gabungan (IHSG) di Bursa Efek Indonesia. Dari hasil estimasi diperoleh nilai koefisien regresi sebesar 276.146. nilai tukar rupiah ditingkatkan/diturunkan sebesar 1 satuan, maka nilai indeks harga saham (Y) akan meningkat /menurun pula sebesar 276.146 poin, dengan asumsi variabel independen lain konstant. Dan nilai t hitung diperoleh $\mathrm{t}$ hitung $=7,417$ dan $\mathrm{t}$ tabel $=$ pada $\alpha$ $=0,05=2.000$ ini menunjukkan $\mathrm{H}_{0}$ ditolak dan $\mathrm{H}_{1}$ diterima. Karena $\mathrm{t}$ hitung=7,417 > $\mathrm{t}$ tabel $=2,000$. Dengan demikian, terdapat pengaruh nilai tukar rupiah tengah US dollar $(\mathrm{X})$ terhadap indeks harga saham gabungan (Y).

Hasil studi memberikan arti bahwa penguatan nilai tukar rupiah terhadap US dollar akan diikuti oleh kenaikan indeks harga harga saham gabungan (IHSG). Secara teoritis ada 
beberapa dasar pemikiran yang mendukung pengaruh nilai tukar rupiah/US dollar terhadap indeks harga saham gabungan (IHSG) dapat dijelaskan dengan melalui pendekatan keseimbangan portfolio Menurut Bailie and Mc Mahon, 1990. ${ }^{16}$ Pendekatan ini berkeyakinan bahwa kurs valas dan suku bunga ditentukan secara simultan melalui kondisi keseimbangan portfolio bagi pemegang aset di masing-masing suatu negara. Karena aset mempunyai sifat saling menggantikan secara tidak sempurna. Berdasarkan konsep ini, setiap perubahan kekayaan akan berdampak pada meningkatnya permintaan financial lain dan adanya subtitusi suatu asset financial dengan aset financial lain yang lebih menguntungkan. Pada analisis keseimbangan porfolio, rupiah/US dollar dapat digabungkan dengan aset financial lain seperti saham. oleh karenanya, apabila permintaan rupiah terhadap US dollar turun, maka rupiah akan terdepresiasi terhadap US dollar atau melemah. Jika nilai rupiah terdepresiasi terhadap US dollar, maka investor akan cenderung mengalihkan dananya dalam bentuk investasi lainnya.

Nilai tukar mencerminkan keseimbangan permintaan dan penawaran terhadap mata uang dalam negeri maupun mata uang asing/US dollar. Merosotnya nilai tukar rupiah merefleksikan menurunnya permintaan masyarakat internasional terhadap mata uang rupiah karena menurunnya peran perekonomian nasional atau karena meningkatnya permintaan mata uang asing/US dollar oleh masyarakat karena perannya sebagai alat pembayaran internasional.

Kurs valas juga dapat mempengaruhi arus kas perusahaan, khusunya bagi perusahaan yang sudah go publik yang mempunyai orientasi ekspor dengan suplai bahan baku lokal, maka apabila terjadi apresiasi mata uang asing akan memberikan keuntungan bagi perusahaan tersebut. Pendapatan dengan jumlah valas yang sama, perusahaan akan memperoleh jumlah mata uang lokal yang lebih banyak apabila dikonversikan. Di lain pihak, perusahaan yang memproduksi barang dengan kandungan bahan baku impor yang tinggi dan mengutamakan penjualan dalam negeri akan sangat menderita dengan adanya apresiasi mata uang asing. Dengan jumlah bahan baku impor yang sama perusahaan membutuhkan mata uang domestik yang lebih banyak untuk dikonversikan ke dalam mata uang eksportir. Hal ini akan meningkatkan arus kas keluar perusahaan. Apabila arusa kas keluar lebih besar daripada arus kas masuk tentu saja perusahaan ini akan mengalami kerugian. Dalam kondisi apresiasi mata uang asing perusahaan jenis ini kurang menarik

\footnotetext{
${ }^{16}$ Chirs Bilson, Brailsford Tim, and Hooper Vince. "Selecting Macro Economic Variables as Explanatory Factors of Emerging Stock Market Return.” Pacific Basin Finance Journal, Vol. IX No. 4, 2011.
} 
bagi para investor, bila diikuti dengan tindakan menjual saham oleh para investor maka harga saham perusahaan tersebut akan menurun. Jika hal ini dialami banyak perusahaan maka akan menurunkan indeks harga saham gabungan (IHSG).

Pendekatan portofolio berpendapat lain bahwa pasar modallah yang justru mempengaruhi kurs melalui permintaan akan uang. Pendekatan ini menekankan adanya hubungan positif antara harga saham dan kurs, bahwa fluktuasi harga sahamlah yang mempengaruhi fluktuasi kurs. Harga saham yang turun akan membuat permintaan uang turun, yang pada akhirnya menyebabkan suku bunga juga turun. Mata uang yang suku bunganya turun selanjutnya akan mengalami depresiasi (pelemahan nilai tukar).

Terdapat dua pendekatan teori yang dikembangkan dalam literatur untuk menentukan hubungan antara kurs mata uang dengan harga saham. Pertama, good market approach (Dornbusch dan Fischer) menyatakan perubahan mata uang atau kurs mempengaruhi competitiveness suatu perusahaan, yang selanjutnya mempengaruhi pendapatan perusahaan atau cost of fund dan selanjutnya harga sahamnya. Berdasarkan macro basis dampak fluktuasi kurs mata uang terhadap pasar modal sangat tergantung pada tingkat keterbukaan ekonomi domestik dan kesinambungan neraca perdagangan; Kedua, portfolio balance approach (Franke) dimana menekankan peranan capital account transactions. Kenaikan return saham (rising stock market) akan menarik capital flow yang selanjutnya akan meningkatkan demand mata uang domestik dan menyebabkan kurs mata uang terapresiasi. Sekalipun menurut teori terdapat causal relationship antara kurs mata uang dengan harga saham yang akan berdampak pada perubahan nilai indeks harga saham secara keseluruhan (IHSG), bukti yang ada menunjukkan hubungan yang lemah diantara keduanya pada tataran mikro. ${ }^{17}$

Kurs rupiah dengan kurs mata uang asing akan mempengaruhi harga saham seluruh emiten. Hal ini bisa juga dijelaskan dengan asumsi sebagai berikut: kurs rupiah akan mempengaruhi penjualan perusahaan (terutama untuk emiten yang berorientasi bisnis ekspor), Cost Of Good Sold (mempengaruhi pembelian bahan baku apabila diperoleh dari impor), dan rugi kurs. Khusus untuk rugi kurs, terutama bagi perusahaan yang memiliki kewajiban dalam mata uang asing, akan sangat terpengaruh oleh depresiasi maupun apresiasi rupiah. Menurunnya nilai tukar rupiah terhadap mata uang asing (dolar amerika) akan berdampak terhadap meningkatnya biaya impor bahan baku dan peralatan yang

\footnotetext{
${ }^{17}$ Budiono, Ekonomi Makro, Ed. I (Surabaya: Penerbit Erlangga, 1993), h. 196.
} 
dibutuhkan perusahaan, sehingga menyebabkan terjadinya peningkatan terhadap biaya produksi. Peningkatan biaya produksi akan mengurangi laba perusahaan, sehingga akan menurunkan harga saham-saham khususnya perusahaan yang mempergunakan bahan baku impor. Di sisi lain, melemahnya nilai tukar rupiah terhadap US Dollar akan berdampak negatif terhadap ekonomi nasional karena akan membuat keadaan bergejolak, sehingga para investor akan bersiap menyimpan dananya dalam bentuk dalam mata uang dollar. Kondisi tersebut, pada akhirnya menurunkan kinerja pasar modal karena tekanan dari perubahan nilai tukar mata uang yang meningkatkan beban perekonomian nasional dan akan berdampak pada setiap perusahaan. Dampak selanjutnya, akan membuat ketidak pastian pada bisnis saham, sehingga akan mengurangi minat para investor untuk bertransaksi dengan alasan mereka takut terjadi risiko. Berdasarkan pandangan tersebut, maka dapat disimpulkan bahwa, menurunnya nilai tukar rupiah terhadap US dollar akan menyebabkan permintaan terhadap berbagai jenis saham berkurang. Kondisi tersebut dapat mendorong turunnya nilai indeks harga saham gabungan (IHSG) sebagai akibat dari menurunnya volume transaksi serta nilai transaksi saham yang terjadi setiap saat.

\section{G. Kesimpulan}

Hasil penelitian membuktikan bahwa nilai tukar rupiah terhadap/ US dollar berpengaruh positif signifikan terhadap indeks harga saham gabungan (IHSG) di Bursa Efek Indonesia. Dari hasil estimasi diperoleh nilai koefisien regresi sebesar 276.146. nilai tukar rupiah ditingkatkan/diturunkan sebesar 1 satuan, maka nilai indeks harga saham (Y) akan meningkat /menurun pula sebesar 276.146 poin, dengan asumsi variabel independen lain konstant. Dan nilai t hitung diperoleh $\mathrm{t}$ hitung $=7,417$ dan $\mathrm{t}$ tabel $=$ pada $\alpha=0,05=$ 2.000 ini menunjukkan $\mathrm{H}_{0}$ ditolak dan $\mathrm{H}_{1}$ diterima. Hasil studi memberikan arti bahwa penguatan nilai tukar rupiah /US dollar akan diikuti oleh kenaikan indeks harga harga saham gabungan (IHSG). Secara teoritis ada beberapa dasar pemikiran yang mendukung pengaruh nilai tukar rupiah/US dollar terhadap indeks harga saham gabungan (IHSG). 


\section{DAFTAR PUSTAKA}

Aswath, Damodaran. Investment Valuation: Tools and Techniques for Determine the Value of Any Asset. New York. John Wiley \& Sons, Inc, 1996.

Basu, Swasta. "Investment Performance of Common Stock in Relation to Their Price Rations: A Test of the Market Efficiency Hypotesis," Journal of Finance, Vol. 23, 1997.

Berry, A. Michael, Edwin Burmeister, and Majorie B. Mc Elroy. "Risks Using Known APT Factors." Financial Analysis Journal, Vol 44, 1988.

Bilson, Chirs, Brailsford Tim, and Hooper Vince. "Selecting Macro Economic Variables as Explanatory Factors of Emerging Stock Market Return." Pacific Basin Finance Journal, Vol. IX No. 4, 2011.

Budiono. Ekonomi Makro, Ed. I. Surabaya: Penerbit Erlangga, 1993.

Bursa Efek Indonesia, JSX Monthly Statistik, Vol. 20, No. 1-12, 2016.

Chan, Louis K.C., Yasushi Harmao, and Josef Lakonishok, "Can Fundamentals Predict Japanase Stock Returns," Financial Analysist Journal, No. 4, Vol 49 Juli/Agustus, 1993.

Chandra, Prasanna. Investment Analysis and Portfolio Management. Second Edition, CFMTHM Professional Series in Finance. New Delhi, Tata McGraw-Hill Publishing Company Limited, 2005.

Husnan S., Dasar-Dasar Teori Portofolio dan Analisis Sekuritas. UPP-AMP, 1989.

Syamsul, Muhammad. Pasar Modal dan Manajemen Portofolio. Surabaya: Airlangga, 2006.

http://id.wikipedia.org

http://id.wikipedia.org/wiki/ saham \# riwayat-saham 